\title{
A review of recent research on the microbial control of Californian thistle and other pasture weeds using the fungus Sclerotinia sclerotiorum as a biological herbicide
}

\author{
G.W. BOURDÔT and I.C. HARVEY \\ AgResearch, PO B ox 60 Lincoln, New Zealand
}

\section{Abstract}

In this paper we review the research findings published to date on the development of a plant pathogenic fungus, Sclerotinia sclerotiorum, as a mycoherbicide for Californian thistle, Cirsium arvense, and other weeds of pastures. A strain of the fungus isolated from Californian thistle was virulent also on Scotch thistle (Cirsium vulgare), nodding thistle (Carduus nutans) and ragwort (Senecio jacobaea) when applied as a myceliumon-wheat formulation to the foliage of these weeds under glasshouse conditions. In field trials in which this formulation of the mycoherbicide was applied to the new spring foliage of Californian thistle in Canterbury sheep pastures, the thistle was controlled, to a high level both in the season of application and during the following growing season. Debilitation of root systems of the thistle occurs through reductions in photosynthetic capacity through death of treated shoots, and by invasion and rotting of roots by the pathogen. The strain of the fungus used in the field trials did not -infect-either-grasses-otclor_ers. The results of research to date indicate that $\mathbf{S}$. sclerotiorum has considerable potential as a mycoherbicide for use in pastures against Californian thistle and some other species of weeds

Keywords: biological weed control, Carduus nutans, Cirsium arvense, Cirsium vulgare, mycoherbicide, Sclerotinia sclerotiorum, Senecio jacobaea

\section{Introduction}

Many weeds impede pastoral farming in New Zealand and one of the most important is Californian thistle, Cirsium arvense, a perennial widely distributed in the temperate agricultural zones of both hemispheres (Holm et al. 1977). In New Zealand it occurs in pastures and crops (Cockayne 1917; Bascand \& Jowett 1982; Bourdôt \& Kelly 1986) where population increase occurs by adventitious shoots from the creeping root system and by the establishment of seedlings on open land. Despite recommendations involving cultivation, herbicides and grazing (Hartley \& Butler 1984; Hartley et al. 1984; Meeklah \& Mitchell 1984). Californian thistle is rarely adequately controlled. Furthermore, the herbicides commonly used against the weed in pastures (MCPA, 2,4-D, dicamba) remove nitrogen-fixing clovers from the treated sward, reducing pasture production. As a consequence of the tenacity of this weed, the 'classical' biological control approach has been attempted. To this end three exotic phytophagous insects (Urophora cardui, Lema cyanella, and Altica carduorum) have been released in New Zealand over the last 19 years (Jcssep 1989). Unfortunately $L$. cyanella only has established but to date has not controlled the thistle (Jessep 1989). An alternative biological approach was first investigated about 10 years ago in the USA when a soil-applied mycelial/ whole wheat grain preparation of Sclerotinia sclerotiorum (Lib.) de Bary, a common fungal pathogen of Californian thistle and several important crop species (Pennycook 1989), was field-tested as a mycoherbicide against the thistle in Montana (Brosten \& Sands 1986). However, because of the variable results in the field, and the very high application rates (500 to $1000 \mathrm{~kg} / \mathrm{ha}$ ) as a consequence-of-using-whole-seeds-as-the food source/carrier for the fungus, commercial interest in the USA declined and a mycoherbicide based on $\mathrm{S}$. sclerotiorum was never developed..

Research began in New Zealand'on $S$. sclerotiorum and its use as a mycoherbicide in 1989 following the success of greenhouse trials on Californian thistle using a foliage applied mycelium-on-kibbled wheat formulation. In this paper we summarise the research published to date and discuss the potential and limitations of this broad-host-range pathogen for controlling Californian thistle and several- otherherbaceous pasture weeds.

Experiments on the pathogenicity of $S$. sclerotiorum on thistles and other pasture weeds

Waipara et al. (1993) reported the results of two experiments in which an isolate of $S$. sclerotiorum (S9) from a Californian thistle plant in Canterbury, was 
tested for virulence on several weed species. Inoculum containing about 15000 colony forming units per gram was prepared by growing the pathogen on kibbled wheat and milling to a tine granule. This was applied to premisted plants in a glasshouse at an equivalent rate of $50 \mathrm{~g} / \mathrm{m}^{2}$. In the first experiment 12 plants (one per pot) of each of the following weeds were inoculated: Californian thistle, nodding thistle (Carduus nutans), winged thistle (Carduus tenuiflorus), Scotch thistle (Cirsium vulgare), and broad-leaved dock (Rumex obtusifolius). In the second experiment, eight plants each of Californian thistle, hawksbeard (Crepis capillaris), catsear (Hypochaeris radicata), dandelion (Taraxacum officinale) and ragwort (Senecio jacobaea) were inoculated. Mortality was assessed 12 and 18 days after inoculation in Experiments 1 and 2 respectively. The $S$. sclerotiorum infected all species, but some were more affected than others with symptoms ranging from superficial lesions on leaf laminae to general necrosis and death of whole plants. Californian, Scotch and nodding thistles and ragwort had high levels of mortality (Table 1). However, there was no mortality in broadleaved dock, hawksbeard, dandelion or catsear although the pathogen caused variable levels of leaf necrosis in these species.

Table 1 Plant mortality in nine species of weeds following inundative foliage inoculation with a mycelium-onwheat formulation of Sclerotinia sclerotiorum under glasshouse conditions. Mortalities were determined 12 and 18 days after inoculation in Experiments 1 and 2 respectively. (Adapted from Waipara et al. 1993).

Mortality (\%)

\begin{tabular}{lr}
\hline Experiment 1 & \\
Californian thistle (Cirsium arvense) & 100 \\
Scotch thistle (Cirsium vulgare) & 75 \\
nodding thistle (Carduus nutans) & 58 \\
winged thistle (Carduus tenuiflorus) & 8 \\
broad leaved dock (Rumex obtusifolius) & 0 \\
Experiment 2 & \\
Californian thistle & 100 \\
Ragwort (Senecio jacobaea) & 50 \\
Hawksbeard (Crepis capillaris) & 0 \\
Dandelion (Taraxacurn otficinale) & 0 \\
Catsear (Hypochaeris radicata) & 0
\end{tabular}

\section{Evaluation of S. sclerotiorum for Californian thistle control in pastures}

An experiment was conducted by Bourdôt et al. (1993) at three sites in Lolium perenne/Trifolium repens pastures at Templeton from October 1991 until September 1992. They were 10 years old and supported extensive populations of $\mathrm{C}$. arvense. They were flood- irrigated several times during the summer and were rotationally grazed by sheep.

At site 1 three treatments were replicated four times; (1) untreated control, ('2) S. sclerotiorum applied on 12 October 1991 to the newly emerged spring cohort of adventitious shoots, (3) S. sclerotiorum applied on 12 October followed by retreatment on 15 November when stem elongation and flower bud initiation were occurring in the thistle, At sites 2 and 3 a fourth treatment on 15 November only was included. The treatments used the formulation described above which was broadcast by hand at 50 $\mathrm{g} / \mathrm{m}^{2}$ onto small plots. Other experimental details are described by Bourdôt et al. (1992).

Within 7 days of application, leaf and stem lesions caused by $\boldsymbol{S}$. sclerotiorum were apparent on most of the thistle shoots in the treated plots. Typically lesions developed from the granules of inoculum adhering to the upper surface of lower leaves close to the junction with the stem. These lesions then increased in size and enveloped the stem. Shoot growth slowed markedly and the upper leaves developed after treatment became chlorotic and whole shoots soon wilted and died. Most deaths due to the pathogen occurred within 30 days of treatment. Regrowth from axillary buds on stems below the ground rarely occurred; any regrowing shoots soon died as the pathogen invaded the new tissue from the dead parent tissue.

Figure 1 The effect of timing of applications of the experimental formulation of Sclerotinia sclerotiorum in 1991 on the ground cover of Cirsium arvense in January 1992. The data given are the means over the three sites. Vertica lines are $\mathrm{LSD}(\mathrm{P}<0.05)$ values. The lefthand $\mathrm{LSD}$ is for comparing the October treatment with the double October/November treatment The righthand LSD is for comparing the November treatment with untreated. The middle LSD is for all other comparisons. (From Bourdôt et al. 1993).

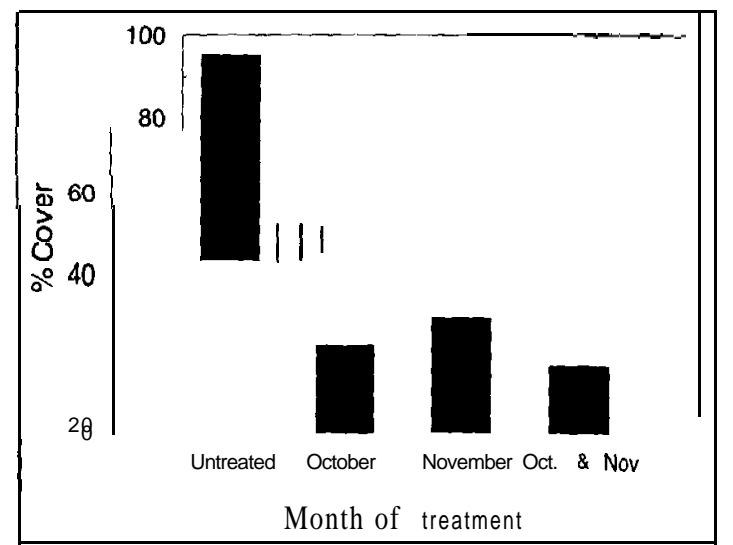


Averaged over the three sites, all treatments significantly reduced the ground area covered by the thistle when measured on 28 January 1992 in the season of treatment but there were no significant differences between the treatments (Figure 1). Application in October reduced the area covered by thistle to $42 \%$, in November to $55 \%$, and in October and November to $32 \%$ of untreated.

The percentage of ground area covered by the thistle and the density of shoots on the 14 December 1992 in the growing season after treatment, is given for Site 1 in Figure 2. The effects on thistle ground cover in the year of treatment at Site 1 mimic the effects averaged over the three sites (Figure $2 \mathrm{a} c \mathrm{c}$. Figure 1). On 14 December, 14 and 13 months respectively after the October and November 1991 treatments, the ground cover of the 1992 population of thistle shoots on the treated plots was only $19 \%$ of untreated (Figure 2b). In addition the densities of the shoot populations in December 1992 on the plots treated in October and October plus November 1991, were $48 \%$ and $39 \%$ of untreated respectively. Since the proportional reduction was less for shoot density than it was for percentage ground cover, the shoots apparently had less leaf area on the treated plots than on the untreated in the year after treatment. These shoots were less than half as tall as those on the untreated plots and flowered later and less profusely.

\section{Selectivity of $\boldsymbol{S}$. sclerotiorum in grass/clover pasture}

Hurrell \& Bourdôt (1993) conducted an experiment on a Templeton silt loam in Canterbury to compare the effects of S. sclerotiorum and MCPA (the usual treatment for this weed) on pasture grasses and clovers. The pasture was 12 years old and contained perennial ryegrass (cv. Ellett) and white clover (cv. Grasslands Huia); Californian thistle was absent. Two treatments were applied on 2 November 1992; (1) MCPA at 1.5 $\mathrm{kg} / \mathrm{ha}$ (IWD MCPA, $375 \mathrm{~g} /$ litre) and (2) the myceliumon-wheat preparation of S. sclerotiorum described above at $500 \mathrm{~kg} / \mathrm{ha}$. An untreated control- was also included. Other experimental details are given in Bourdôt \& Hurrell (1993).

The dry matter yields of white clover and ryegrass on four harvest occasions are given in Figure 3. The yield of white clover was greatly reduced by MCPA at each time, The percentage reductions were $85 \%$, $90 \%, 74 \%$ and $71 \%$ at $23,65,118$ and 168 days after treatment (DAT) respectively. There was no evidence that $S$. sclerotiorum reduced the clover yields. Neither MCPA nor $S$. sclerotiorum reduced ryegrass yields.

This experiment demonstrated the severe effects
Figure 2 The effect of spring applications of the experimental formulation of Sclerotinia sclerotiorum in 1991 on Cirsium awense at Site 1; (a) \% ground cover of C. arvense shoots on 28 January 1992 and (b) \% ground cover and density of shoots on 14 December 1992; the year after treatment. The vertical lines to the left of the lefthand bars in (a) and(b) are the $\mathrm{LSD}(\mathrm{P}<0.05)$ values for comparing \% ground covers between treatments; the line to the right of the lefthand hatched bar in (b) is the $\operatorname{LSD}(\mathrm{P}<0.05)$ for comparing shoot densities between treatments. (From Bourdôt et al. 1993).

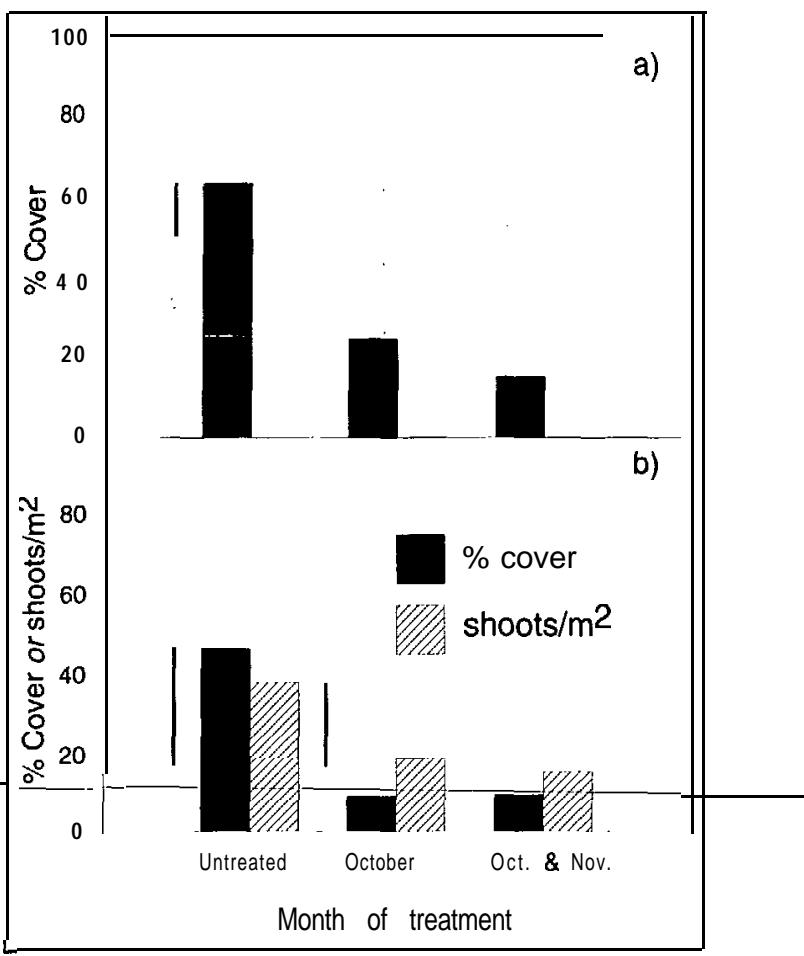

of MCPA on clovers that have been documented by others (Thompson 1956; Maclean 1957; Meeklah 1958; Meeklah \& Mitchell 1984; Honore et al. 1980) but provided no evidence that the $S$, sclerotiorum affected-white-clover production. The effect-of MCPA on the clover lasted almost the entire growing season. Previous research has attempted to determine the impact of this on livestock production. Hartley \& Thomson (1982) reported that repeat applications of MCPA at $1 \mathrm{~kg} / \mathrm{ha}$, reducing clover cover by $37 \%$. caused an $18 \%$ reduction in liveweight gain in young dairy cattle. Lewis (1956) showed that a single application of MCPA at $1.1 \mathrm{~kg} / \mathrm{ha}$ gave approximately $75 \%$ reduction in clover productivity resulting in a $15 \%$ reduction in liveweight gain in pre-weaned lambs during the month immediately following treatment. 
Figure 3 The effect of Sclerotiniasclerotiorum and MCPA on the productivity of ryegrass and clover on four occasions after treatment. Yields given as backtransformed means of the logarithms $\left(\log _{10}\right)$ of the data. Values above each group of three treatments are the Least Significant Ratios $(P<0.05)$. Treatment means are significantly different if the ratio between them is greater than the LSR (e.g. for the first occasion, one clover dry matter mean differs significantly from another mean if it is 1.8 times greater). (From Hurrell \& Bourdôt 1993).

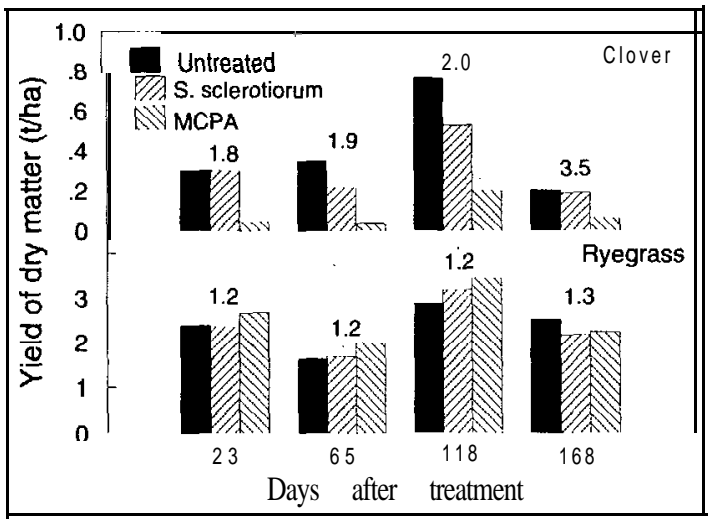

\section{Discussion}

The term mycoherbicide is applied to fungal plant pathogens when used inundatively to control a weed population. The chose? pathogens are often already present in the country or region but affect the target weed only spasmodically as a result of natural constraints to epidemic development. This approach to biological weed control stands in contrast to the more conventional "classical" biological control where the pathogen (or other agent e.g. an insect) is imported from another country or region and is released, after thorough testing, to build up population levels that eventually may suppress populations of the target weed.

The pathogen we have chosen as a mycoherbicide for pasture weed control in New Zealand is $S$. sclerotiorum. Its advantages are the ease with which its mycelial phase can be cultured en masse and its naturally high pathogenicity towards a variety of pasture weeds. It appears from initial virulence tests with S. sclerotiorum (strain $\mathrm{S} 9$ ) that in addition to Californian thistle, from which this strain was obtained, Scotch thistle, nodding thistle and ragwort are also excellent candidates for a mycoherbicide using this pathogen (Table 1). The last two species were hitherto unknown as hosts of S. sclerotiorum
(Pennycook 1989; Farr et al. 1989). Although there was no mortality in broadleaved dock, hawksbeard, dandelion or catsear, and only $8 \%$ mortality in winged thistle, all plants of these species were infected by the pathogen. Neither catsear nor hawksbeard have been recorded as hosts to $\boldsymbol{S}$. sclerotiorum (Pennycook 1989; Farr et al. 1989). Other strains may be more effective on these weeds than strain $\mathbf{S} \boldsymbol{9}$ used in the experiments. This contention is supported by recent research by Riddle et al. (1991) showing that the mortality rates of dandelion in turfgrass after application of different strains of $\boldsymbol{S}$. sclerotiorum, was positively-correlated with the in vitro virulence of the strains; mortality in the field was as high as $81 \%$ with the most virulent strain.

To date only Californian thistle has been the subject of field evaluations and the results have been most encouraging (Figures 1 and 2). When applied as a mycelium-on-kibbled wheat formulation to the foliage of the thistle in spring, S. sclerotiorum (S9) was effective in reducing the pasture cover of the thistle in the year of application. It achieved this by killing a high proportion of the shoots present at the time of application. The effect of the pathogen was evident again in summer of the year after treatment when the treated shoot population consisted of fewer shoots. This implies that the regenerative capacity of the root system had been reduced by the pathogen. This effect on the roots was probably due in part to the reduction in photosynthetic capacity of the thistle stands which would have resulted in reduced ability to support current roots and reduced ability to produce new roots. In addition the pathogen invades the roots down to a depth of at least $300 \mathrm{~mm}$ (Bourdôt et al. 1994) causing them to rot.

The shoots emerging on treated plots the year after treatment were developmentally delayed and several explanations seem possible for this. While root death provides an explanation for the lower density of shoots in the season after treatment, it is difficult to see how root death per se could result in smaller or develop-mentally delayed shoots in the year after treatment. A possible explanation is that the pathogen persisted in root tissue over winter, and weakened the spring shoots by continuing to destroy feeding roots in the year after treatment. New infections may also have occurred from overwintering sclerotia, and weakened the developing shoots. There was however no evidence of shoot mortality due to $S$. sclerotiorum on the treated plots the year after treatment. The reason for reduced shoot vigour the year after treatment, will remain obscure until more definitive studies, which are currently underway, are completed. 
The mycelium-on-wheat formulation used in this research was applied in the field at $500 \mathrm{~kg} / \mathrm{ha}$. Application rates as high as this are obviously neither feasible nor would they be commercially viable broadcast over large areas of pasture. A food source must be applied along with the fungal mycelium in order to allow a period of saprophytic growth to facilitate eventual pathogenesis. The research to date has used kibbled wheat but AgResearch has recently entered into a 3-year research partnership with ICI Crop Care to develop a formulation that has both the necessary biological characteristics and commercial viability.

The results from this first experimental use of a fungus as a biological herbicide in New Zealand, show that $\boldsymbol{S}$. sclerotiorum has potential for controlling Californian thistle and other weeds in pastures. The lack of any substantial effect on pasture grasses and clovers contrasts with the debilitation of clovers which follows the use of MCPA (Figure 3). Its wide host range maybe a "two-edged-sword" for whilst this widens its market potential as a bio-herbicide, it carries with it the risk of disease incitement in adjacent or subsequent susceptible crops. This risk may be averted by spatial and temporal containment of the pathogen in the inoculated field by employing auxotrophic or nonsclerotial mutants (Miller et al. 1989a; 1989b; Sands et al. 1990) or heterokaryons (Forde et al. 1992) rather than wildtypes. However the risk of using a wildtype S. sclerotiorum is unknown, expect in a qualitative sense. Research is therefore required to evaluate this risk. It does not necessarily follow that a mycoherbicide based on a fungus with a broad host range presents an_unacceptable_risk-to-susceptible crops. The risk analysis conducted by de Jong et al. (1990) showed that the widely occurring fungus Chondrostereum purpureum, which causes silverleaf disease in fruit trees, could be safely used as a mycoherbicide against the weedy tree Prunus serotina in pine forests in the Netherlands without increasing the risk of the disease in adjacent fruit growing areas.

\section{REFERENCES}

Bascand,-L.D:; Jowett, G.H.-1982. Scrubweed cover-ofSouth Island agricultural and pastoral land. 2. Plant distribution and managerial problem status. New Zealand journal of experimental agriculture 10: 455-492.

Bourdôt, G.W.; Harvey, I.C.; Hurrell, G.A.; Alexander, R.T. 1993. An experimental mycoherbicide utilizing Sclerotinia sclerotiorum controls pasture populations of Cirsium arvense in Canterbury. Proceedings 46th NZ Plant Protection Conference: 251-256.
Bourdôt, G.W.; Harvey, I.C.; Hurrell, G.A.; Saville, D.J. 1994. Demographic and biomass production consequences of inundative treatment of Cirsium arvense with Sclerotinia sclerotiorum. Biocontrol science and technology. In press.

Bourddt, G.W.; Kelly, D. 1986. Density and cover estimates of some non-palatable herbaceous pasture weeds. Proceedings 39th N.Z. Weed \& Pest Control Conference: 183-I 86.

Brosten, B.; Sands, D. 1986. Field trials of Sclerotinia sclerotiorum to control Canada thistle (Cirsium arvense). Weed science 34: 377-380.

Cockayne, A.H. 1917. Noxious weeds in New Zealand. Journal of Agriculture 14: 339-344.

de Jong, M.D.; Scheepens, P.C.; Zadocks, J.C. 1990. Risk analysis for biological control: A Dutch case study in biocontrol of Prunus serotina by the fungus Chondrostereum purpureum. The plant disease 74 : 189-194.

Farr, D.F.; Bills, G.F.; Chamuris, G.P.; Rossman, A.Y. 1989. Fungi on plants and plant products in the United States. APS Press - American Phytopathological Society, Minnesota, USA.

Forde, E.J.; Casquilho, H.; Miller, R.V.; Sands, DC. 1992. First report of heterokaryon formation by Sclerotinia sclerotiorum. Abstract (A181) of the joint meeting of The American Phytopnthological Society and the Mycological Society of America, Portland, 1992.

Hartley, M.J.; Thomson, N.A. 1982. Effect and control of Californian thistle in dairy pasture. Proceedings NZ Grassland Association 43: 104- 107.

-Hartley-M-J:;-Butler,-J-H:B-1984- Cālifornian thistte - weed of pasture and crops - biology and control. Aglink FPP 651, MAF Information Services, Wellington.

Hartley, M.J.; Lyttle, L.A.; Popay, A.I. 1984. Control of Californian thistle by grazing management. Proceedings 37th New Zealand Weed and Pest Control Conference: 24-27.

Holm, L.G.; Plucknett, D.L.; Pancho, J.V.; Herberger, J.P. 1977. Cirsium arvense (L.) Scop. In: The world's worst weeds - distribution and biology.

East-West Centre, University of Hawaii, pp. 217224.

Honore, E.N.; Rahman, A.; Dyson, C.B. 1980. Effects of winter application of phenoxy herbicides on white clover and pasture production in lower Northland. Proceedings 33rd NZ Weed and Pest Control Conference: 55-58.

Hurrell, G.A.; Bourdôt, G.W. 1993. Pasture grasses and clovers unaffected by an inundative application of Sclerotinia sclerotiorum. Proceedings 46th NZ Plant Protection Conference: 257-260. 
Jessep, C.T. 1989. Cirsium arvense (L.) Scopoli, Californian thistle (Asteraceae). In: A review of biological control invertebrate pests and weeds in New Zealand 1874-1987. (ed P.J.)

Maclean, S.M. 1957. Effect of time of spraying on pasture production. Proceedings 10th NZ Weed Control Conference: 34-43.

Meeklah, F.A.; Mitchell, R.B. 1984. Evaluation of herbicides for control of Californian thistle.

Proceedings 37th New Zealand Weed and Pest Control Conference: 20-23.

Meeklah, W.F.A. 1958. Comparison of the substituted phenoxy-acetics and the phenoxy-butyrics on a white clover-perennial ryegrass. Proceedings $11 \mathrm{th}$ NZ Weed Control Conference: 61-67.

Miller, R.V.; Ford, E.J.; Zidack, N.J.; Sands, D.C. 1989b. A Pyrimidine auxotroph of Sclerotinia sclerotiorum for use in biological weed control. Journal of general microbiology 135: 20855291.
Miller, R.V.; Ford, E.J.; Sands, D.C. 1989a. A nonsclerotial mutant of Sclerotinia sclerotiorum. Canadian journal of microbiology 35: 5 17-520.

Pennycook, S.R. 1989. Plant diseases recorded in New Zealand. Plant Diseases Division, DSIR, Auckland.

Riddle, E.; Burpee, L.L.; Gregory. F.L. 1991. Virulence of Sclerotinia sclerotiorum and S. minor on dandelion (Taraxacum officinale) Weed science 39: $109-118$

Thompson, F.B. 1956. Clover tolerance. Proceedings 9th NZ Weed Control Conference: 89-93.

Waipara, N.W.; Harvey, I.C.; Bourdôt, G.W. 1993. Pathogenicity of Sclerotinia sclerotiorum on common thistle species and other pasture weeds. Proceedings 46th NZ Plant Protection Conference: 261-264. 